\title{
Formulasi dan karakteristik nutrimat bar berbasis tepung kacang kedelai (glycine max. L) dan tepung kacang merah (phaseolus vulgaris. L) sebagai makanan pasien kemoterapi
}

\author{
I Gusti Agung Gede Wiranata1, Dylla Hanggaeni Dyah Puspaningrum ${ }^{1}$, I Gusti Ayu Wita Kusumawati ${ }^{1}$
}

\begin{abstract}
Background : The potency of soybeans and red beans as the source of antioxidant agents is very interesting to be developed as snack bar for chemotherapy patients. Nutrimat bar is made with addition of soybeans flour and red beans flour. The correct formulation will result in good characteristic of nutrimat bar.

Methods : This research used Complete Random Design (RAL) with five types of treatment and three times of repetition. The formulations of soybeans flour and red beans flour being used were $P_{1}(0: 100) ; P_{2}(25: 75) ; P_{3}(50: 50) ; P_{4}(75: 25) ;$ and $P_{5}$ (100:0). Analysis to nutrimat bar was sensory characteristic analysis (taste, flavor, color and texture) and nutrient content analysis (protein, fat, carbohydrate and antioxidant). Data analysis used ANOVA with further testing of Smallest Real Difference (BNT).

Results : The result of research shows that formulation with addition of soybeans flour and read beans flour has an effect towards characteristic of nutrimat bar quality being produced.

Conclusion : The best nutrimat bar is made from formulation of $P_{2}$ (soybeans flour of $25 \%$ and red beans flour of $75 \%$ ) which producing characteristic of savory taste, non-rotten flavor, brown color and tender texture, with nutrient content value of protein at $12.75 \mathrm{~g}$, fat at $4.71 \mathrm{~g}$, carbohydrate at $35.36 \mathrm{~g}$ and antioxidant at $84.69 \mathrm{mg} / \mathrm{L}$ Galic Acid Equivalent Antioxidan Capacity $(G A E A C)$.
\end{abstract}

Keywords: soybeans flour, red beans flour, formulation, characteristic, nutrimat bar.

\begin{abstract}
ABSTRAK
Latar Belakang : Potensi kacang kedelai dan kacang merah sebagai sumber antioksidan sangat menarik untuk dikembangkan sebagai snack bar untuk pasien kemoterapi. Nutrimat bar dibuat dengan penambahan tepung kacang kedelai dan tepung kacang merah. Formulasi yang tepat akan menghasilkan karakteristik nutrimat bar yang baik.

Metode : Penelitian ini menggunakan Rancangan Acak Lengkap (RAL) dengan lima jenis perlakuan dan tiga kali ulangan. Formulasi tepung kacang kedelai dan tepung kacang merah yang digunakan adalah $P_{1}(0: 100) ; P_{2}(25: 75) ; P_{3}(50: 50) ; P_{4}$ (75:25) dan $P_{5}(100: 0)$. Analisis terhadap nutrimat bar adalah analisis karakteristik sensoris (rasa, aroma, warna dan tekstur) dan analisis kandungan zat gizi (protein, lemak, karbohidrat dan antioksidan). Analisis data menggunakan ANOVA dengan uji lanjut Beda Nyata Terkecil (BNT).

Hasil : Penelitian ini menunjukkan bahwa formulasi penambahan tepung kacang kedelai dan tepung kacang merah berpengaruh terhadap karakteristik mutu sensorik dan kandungan zat gizi nutrimat bar yang dihasilkan dengan nilai p<0,05.

Simpulan : Nutrimat bar terbaik adalah terbuat dari formulasi $P_{2}$ (tepung kacang kedelai $25 \%$ dan tepung kacang merah $75 \%$ ) yang menghasilkan karakteristik rasa gurih, aroma tidak langu, warna cokelat dan tekstur lembut, dengan nilai kandungan zat gizi protein 12,75 $\mathrm{g}$, lemak 4,71 $\mathrm{g}$, karbohidrat 35,36 $\mathrm{g}$ dan antioksidan 84,69 $\mathrm{mg} / \mathrm{L}$ GAEAC.
\end{abstract}

Kata kunci : tepung kacang kedelai, tepung kacang merah, formulasi, karakteristik, nutrimat bar

\section{PENDAHULUAN}

Kemoterapi merupakan terapi penanganan kanker menggunakan obat-obatan yang bertujuan menghentikan pertumbuhan sel kanker, baik dengan membunuh sel secara langsung maupun dengan menghentikan pembelahan selnya. ${ }^{1}$ Kemoterapi menimbulkan efek samping yang berhubungan dengan masalah makan, seperti : mual, muntah, perubahan pengecapan, berkurangnya produksi air liur, tidak nafsu makan (anoreksia) dan malabsorpsi zat gizi. ${ }^{2}$

\footnotetext{
1. Program Studi Ilmu Gizi, Fakultas Ilmu Kesehatan Sains dan Teknologi, Universitas Dhyana Pura (email korespondensi: agungwiranata.25@gmail.com)
}

Strategi yang dapat dilakukan untuk mengatasi masalah makan pada pasien kemoterapi adalah melalui penyediaan makanan padat dalam porsi kecil namun tinggi akan energi dan protein. ${ }^{2}$ Konsumsi makanan dengan nilai biologis protein tinggi sangat dianjurkan untuk pasien kemoterapi, karena dapat meningkatkan efisiensi penyerapan dan penggunaan nitrogen serta asam amino dalam metabolisme tubuh. ${ }^{3}$ Sumber makanan tinggi antioksidan juga sangat dibutuhkan, karena selain memiliki kemampuan untuk menangkal radikal bebas, senyawa antioksidan juga dapat membantu memberikan nutrisi tambahan kepada sel tubuh yang rusak sehingga dapat segera melakukan regenerasi sel pasca kemoterapi. ${ }^{4}$ 
Snack Bar merupakan makanan padat berbentuk batang yang bisa dikonsumsi sebagai makanan selingan. ${ }^{5}$ Snack Bar pertama kali muncul di supermarket Amerika Serikat pada akhir tahun 1980-an sebagai makanan yang dikonsumsi para atlet. Energi bar dapat dibagi menjadi tiga jenis, yaitu : energi bar sebagai makanan penambah daya untuk olahraga (sport bar), pengganti makanan (meal bar/food bar) dan camilan (snack bar). Masing-masing memiliki karakteristik dan tujuan yang berbeda. ${ }^{6}$ Produksi snack bar sebagai makanan selingan untuk penderita penyakit kronik sudah dikembangkan di luar negeri, namun di Indonesia masih terbatas. ${ }^{5}$ Melihat potensi kacang kedelai dan kacang merah sebagai sumber antioksidan, maka menarik untuk dikembangkan sebagai snack bar untuk pasien kemoterapi. Snack bar akan dibuat dengan penambahan tepung kacang kedelai dan tepung kacang merah. Formulasi yang tepat akan menghasilkan karakteristik snack bar yang baik. Melihat hal tersebut perlu dilakukan penelitian untuk mengetahui formulasi yang tepat pada penambahan tepung kacang kedelai dan tepung kacang merah sehingga diperoleh karakteristik yang baik pada snack bar yang akan dihasilkan.

\section{BAHAN DAN METODE}

Penelitian ini termasuk dalam bidang food production. Jenis penelitian yang digunakan dalam penelitian ini adalah eksperimental dengan Rancangan Acak Lengkap (RAL). Penelitian dilakukan dengan 5 jenis perlakuan, masing-masing perlakuan terdiri dari 3 kali ulangan, sehingga dalam penelitian ini terdiri dari 15 unit percobaan. Perlakuan yang dimaksud, yaitu :

1. $\mathrm{P}_{1}$ : substitusi tepung kacang kedelai $0 \%$ dan tepung kacang merah $100 \%$.

2. $\mathrm{P}_{2}$ : substitusi tepung kacang kedelai $25 \%$ dan tepung kacang merah $75 \%$.

3. $\mathrm{P}_{3}$ : substitusi tepung kacang kedelai $50 \%$ dan tepung kacang merah $50 \%$.

4. $\mathrm{P}_{4}$ : substitusi tepung kacang kedelai $75 \%$ dan tepung kacang merah $25 \%$.

5. $\mathrm{P}_{5}$ : substitusi tepung kacang kedelai $100 \%$ dan tepung kacang merah $0 \%$.

Perlakuan yang dilaksanakan menggunakan perbedaan konsentrasi tepung, bertujuan untuk mendapatkan formulasi dengan karakteristik dan kandungan zat gizi yang terbaik pada produk nutrimat bar. Penelitian ini dilaksanakan pada Unit Pengolahan Makanan Instalasi Gizi RSUP Sanglah Denpasar dan Unit Layanan Laboratorium Fakultas Teknologi Pertanian Universitas Udayana. Waktu penelitian dilaksanakan selama empat bulan, yaitu dari bulan Maret sampai dengan Juni 2017.

Bahan baku pembuatan nutrimat bar, yaitu : tepung kacang kedelai dan tepung kacang merah merek
Gasol diproduksi oleh PT.Gasol Pertanian Organik Cianjur-Jawa Barat, susu bubuk full cream (Indomilk), oat (Quaker), rice crispy (Kellogg's), coklat (Colatta), madu (Nusantara), manisan tomat, manisan wortel, kismis, gula merah, putih telur dan wijen. Bahan kimia yang digunakan untuk analisis kandungan zat gizi (karbohidrat, protein, lemak dan antioksidan), yaitu : HCL 3\%, $\mathrm{NaOH} \mathrm{3,25 \% ,} \mathrm{indikator} \mathrm{PP,} \mathrm{larutan} \mathrm{Luff,}$ $\mathrm{H} 2 \mathrm{O}, \mathrm{KI} 30 \%$, n-hexan, $\mathrm{H} 2 \mathrm{SO} 4$ pekat, tio $0,1 \mathrm{~N}$, tablet Kjeldhal, aquades, asam borat $3 \%$, metanol $p a$ dan larutan DPPH. Alat yang digunakan untuk pembuatan nutrimat bar, yaitu : timbangan kitchen scale Nagako, waskom, loyang, panci, teplon, pisau, talenan, sendok makan, kompor gas dan oven. Alat yang digunakan untuk analisis kandungan zat gizi, yaitu : cawan aluminium, cawan porselin, oven tanur, desikator, kondensor, soxhlet, labu Kjeldhal, alat destilasi, labu erlenmayer, pendingin tegak, labu takar, gelas ukur, hotplate, buret, pipet, kertas saring, penjepit dan spektofotometer Genesys 10S UV-Vis merek Thermo Scientific. Instrumen yang digunakan dalam uji sensoris adalah formulir sensoris dengan 5 skala hedonik meliputi rasa, aroma, warna dan tekstur untuk mengukur tingkat penerimaan nutrimat bar.

Penetapan formulasi kandungan zat gizi pada nutrimat bar berdasarkan perhitungan 10\% dari angka kecukupan zat gizi dalam sehari untuk pasien kemoterapi ${ }^{5}$ sehingga diperoleh kandungan zat gizi, yaitu : energi $275,89 \mathrm{kal}$, karbohidrat $39,7 \mathrm{~g}$, protein $13,09 \mathrm{~g}$, lemak $7,95 \mathrm{~g}$ dan antioksidan $1.083,2 \mathrm{mg}$. Pembuatan nutrimat bar dengan masing-masing perlakuan dan ulangan menggunakan resep yang sama berdasarkan standar resep snack bar, hanya komposisi tepung kacang kedelai dan tepung kacang merah yang berbeda ${ }^{7}$.

Uji sensoris pada nutrimat bar yaitu penilaian terhadap produk dilakukan oleh 25 orang panelis agak terlatih yang merupakan ahli gizi RSUP Sanglah Denpasar. ${ }^{8}$ Pemilihan ini berdasarkan alasan bahwa mereka telah memperoleh pendidikan mengenai penilaian mutu organoleptik atau sensoris. Penilaian dilakukan oleh panelis dengan mengunakan instrumen dalam skala hedonik terhadap rasa, aroma, warna, tekstur dan keseluruhan nutrimat bar. Kandungan zat gizi nutrimat bar yang dianalisis meliputi kadar karbohidrat dengan metode Luff Schoorl, protein diperoleh dengan metode Kjeldahl, lemak dengan metode Soxhlet serta aktivitas antioksidan pangan diperoleh dengan metode DPPH (2,2 dhipenyl - 1pycrilhidrazyil).

Data yang dikumpulkan pada penelitian ini adalah variabel terikat (Independent) meliputi nilai uji sensoris (tingkat penerimaan) dan kandungan zat gizi makro dan mikro nutrimat bar. Data yang terkumpul diolah secara kuantitatif dengan menggunakan analisis statistik untuk mengetahui pengaruh formulasi tepung 
kacang kedelai dan tepung kacang merah terhadap karakteristik dan kandungan zat gizi nutrimat bar. Data yang terkumpul akan ditabulasi, kemudian dihitung jumlah skor tertinggi atau terbaik yang akan dilakukan analisis sidik ragam untuk mengetahui pengaruh perlakuan terhadap parameter yang diuji. Apabila ada pengaruh maka akan dilanjutkan dengan uji Beda Nyata Terkecil (BNT). ${ }^{9}$ Uji statistik yang digunakan dalam penelitian ini adalah analisis sidik ragam ANOVA dengan bentuk Rancangan Acak Lengkap (RAL) pada taraf signifikan 5\%.

\section{HASIL}

\section{Hasil Uji Sensoris}

Hasil uji sensoris didapatkan bahwa perlakuan yang paling disukai adalah formulasi $\mathrm{P}_{2}$ (tepung kacang kedelai : tepung kacang merah $=25: 75 \%$ ) dan yang paling tidak disukai adalah formulasi $\mathrm{P}_{5}$ (tepung kacang kedelai : tepung kacang merah $=100: 0 \%$ ). Hasil ini didapatkan berdasarkan parameter keseluruhan kesukaan, yaitu jumlah hasil mean dari empat parameter (rasa, aroma, warna dan tekstur). Hasil dapat disajikan dalam Tabel 1.

Tabel 1. Hasil Uji Sensoris

\begin{tabular}{cccccc}
\hline Parameter & $\begin{array}{c}\text { Nilai Mean } \pm \text { SD } \\
\text { Tertinggi }\end{array}$ & P & $\begin{array}{c}\text { Nilai Mean } \pm \text { SD } \\
\text { Terendah }\end{array}$ & P & Sig \\
\hline Rasa & $4,37 \pm 0,408$ & 2 & $2,01 \pm 0,374$ & 5 & $0,000^{*}$ \\
Aroma & $4,61 \pm 0,500$ & 2 & $2,23 \pm 0,507$ & 5 & $0,000^{*}$ \\
Warna & $4,47 \pm 0,458$ & 5 & $2,93 \pm 0,554$ & 1 & $0,000^{*}$ \\
Tekstur & $4,15 \pm 0,666$ & 2 & $2,44 \pm 0,678$ & 5 & $0,000^{*}$ \\
Keseluruhan & $15,92 \pm 0,837$ & 2 & $11,61 \pm 0,841$ & 5 & $0,000^{*}$ \\
\hline Keterangan: & & &
\end{tabular}

\section{Hasil Uji Kandungan Zat Gizi}

Hasil uji kandungan zat gizi didapatkan bahwa perlakuan yang memiliki nilai kandungan zat gizi tertinggi untuk energi, protein dan lemak adalah formulasi $\mathrm{P}_{5}$ (tepung kacang kedelai : tepung kacang merah $=100: 0 \%$ ) dan yang terendah adalah formulasi
$\mathrm{P}_{1}$ (tepung kacang kedelai : tepung kacang merah $=$ 0:100\%). Sedangkan untuk kandungan karbohidrat dan antioksidan tertinggi adalah formulasi $\mathrm{P}_{1}$ dan yang terendah $\mathrm{P}_{5}$. Hasil selengkapnya dapat disajikan dalam Tabel 2.

Tabel 2. Hasil Uji Kandungan Zat Gizi

\begin{tabular}{lccccc}
\hline Parameter & $\begin{array}{c}\text { Nilai Mean } \pm \text { SD } \\
\text { Tertinggi }\end{array}$ & P & $\begin{array}{c}\text { Nilai Mean } \pm \text { SD } \\
\text { Terendah }\end{array}$ & P & Sig \\
\hline Energi & $235,47 \pm 10,100$ & 5 & $231 \pm 13,405$ & 1 & $0,987^{*}$ \\
Protein & $13,80 \pm 0,223$ & 5 & $12,49 \pm 0,100$ & 1 & $0,000^{*}$ \\
Lemak & $5,22 \pm 0,560$ & 5 & $4,08 \pm 0,540$ & 1 & $0,035^{*}$ \\
Karbohidrat & $36,08 \pm 2,402$ & 1 & $33,13 \pm 2,251$ & 5 & $0,490^{*}$ \\
Antioksidan & $86,04 \pm 22,51$ & 1 & $82,71 \pm 28,29$ & 5 & $1,000^{*}$ \\
\hline
\end{tabular}

Keterangan:

*Uji sidik ragam ANOVA, signifikan pada level 0,05

Tabel 3. Hasil Perhitungan Pemilihan Formulasi Terbaik Nutrimat Bar

\begin{tabular}{|c|c|c|c|c|c|c|c|}
\hline \multirow[b]{2}{*}{ Formulasi } & \multicolumn{5}{|c|}{$\mathrm{Nh}$} & \multirow[b]{2}{*}{$\Sigma \mathrm{Nh}$} & \multirow[b]{2}{*}{ Rank } \\
\hline & $\begin{array}{l}\text { Kadar } \\
\text { protein }\end{array}$ & $\begin{array}{l}\text { Kadar } \\
\text { lemak }\end{array}$ & $\begin{array}{c}\text { Kadar } \\
\text { KH }\end{array}$ & $\begin{array}{c}\text { Kadar } \\
\text { antioksidan }\end{array}$ & $\begin{array}{c}\text { Keseluruhan } \\
\text { kesukaan }\end{array}$ & & \\
\hline$P_{1}$ & 12,49 & 4,08 & 36,08 & 86,04 & 11,88 & 150,57 & 2 \\
\hline $\mathrm{P}_{2}$ & 12,75 & 4,71 & 35,36 & 84,69 & 15,92 & 153,43 & 1 \\
\hline $\mathrm{P}_{3}$ & 13,08 & 4,91 & 34,47 & 82,71 & 12,39 & 147,56 & 5 \\
\hline $\mathrm{P}_{4}$ & 13,57 & 5,14 & 33,94 & 84,72 & 11,74 & 149,11 & 3 \\
\hline $\mathrm{P}_{5}$ & 13,80 & 5,22 & 33,13 & 84,71 & 11,61 & 148,47 & 4 \\
\hline
\end{tabular}




\section{Hasil Pemilihan Formulasi Nutrimat Bar Terbaik \\ Hasil perhitungan pemilihan formulasi nutrimat bar terbaik menggunakan metode de garmo secara lengkap dapat disajikan dalam Tabel 3.}

\section{PEMBAHASAN}

\section{Hasil Uji Sensoris}

\section{Uji sesoris terhadap rasa}

Rasa yang dihasilkan pada nutrimat bar perlakuan $\mathrm{P}_{2}$ lebih terasa enak dan gurih dibandingkan dengan perlakuan $\mathrm{P}_{5}$. Hal ini dapat disebabkan oleh tepung kacang merah mengandung banyak asam glutamat yang mempengaruhi rasa dari nutrimat bar. Asam glutamat sangat penting peranannya dalam pengolahan makanan, karena dapat menimbulkan rasa yang lezat serta meningkatkan cita rasa pada makanan dengan cara memperbaiki keseimbangan cita rasa makanan olahan. Kacang merah kering per 100 gram, terdapat kandungan asam glutamat sebanyak 190,16 $\mathrm{mg} / \mathrm{g}$ protein ${ }^{10}$. Selain itu menurut hasil penelitian pada tahun 2013 tentang Cookies dari Tepung Kacang Merah untuk Makanan Tambahan Anak Balita menyatakan bahwa rasa gurih protein kacang merah juga lebih dominan pada cookies dengan komposisi tepung kacang merah yang lebih banyak. Jadi dapat kita simpulkan bahwa rasa gurih juga ditimbulkan oleh kandungan protein pada kacang merah. Kombinasi rasa nutrimat bar dengan penambahan tepung kacang merah $75 \%$ lebih disukai daripada nutrimat bar dengan formulasi tanpa menggunakan tepung kacang merah. ${ }^{11}$

Hasil uji statistik menggunakan uji one way anova menunjukkan nilai $\mathrm{P}$ value $=0,000<\alpha=0,05$ maka $\mathrm{H}_{0}$ ditolak, yang artinya ada pengaruh signifikan antar formulasi tepung kacang kedelai dan tepung kacang merah terhadap karakteristik sensoris rasa nutrimat bar. Hasil ini kemudian dilakukan uji lanjut dengan menggunakan uji Beda Nyata Terkecil (BNT) untuk menyatakan beda nyata antar perlakuan. Hasil uji lanjut BNT menunjukkan bahwa rasa kelima nutrimat bar berbeda nyata $(\mathrm{p}<0,05)$. Rasa nutrimat bar yang terbuat dari formulasi $\mathrm{P}_{2}$ berbeda nyata dengan nutrimat bar dari formulasi $\mathrm{P}_{1}, \mathrm{P}_{3}, \mathrm{P}_{4}$ dan $\mathrm{P}_{5}(\mathrm{p}<0,05)$.

\section{Uji sensoris terhadap aroma}

Aroma yang dihasilkan pada nutrimat bar perlakuan $\mathrm{P}_{5}$ lebih beraroma langu dibandingkan dengan perlakuan $\mathrm{P}_{2}$. Hal ini dapat disebabkan oleh kerja enzim lipsigenase yang ada dalam biji kedelai. Enzim ini bereaksi dengan lemak terutama jika saat mengolahnya menggunakan air dingin. Faktor inilah yang menyebabkan bau langu masih terasa saat meminum dan memakan produk olahan dari kacang kedelai. ${ }^{12}$ Semakin banyak tepung kacang kedelai yang ditambahkan, maka aroma nutrimat bar yang dihasilkan lebih beraroma langu dan menjadi kurang disukai.

Hasil uji statistik menggunakan uji one way anova menunjukkan nilai $\mathrm{P}$ value $=0,000<\alpha=0,05$ maka $\mathrm{H}_{0}$ ditolak, yang artinya ada pengaruh signifikan antar formulasi tepung kacang kedelai dan tepung kacang merah terhadap karakteristik sensoris aroma nutrimat bar. Hasil ini kemudian dilakukan uji lanjut dengan menggunakan uji Beda Nyata Terkecil (BNT) untuk menyatakan beda nyata antar perlakuan. Hasil uji lanjut BNT menunjukkan bahwa aroma kelima nutrimat bar berbeda nyata $(\mathrm{p}<0,05)$. Aroma nutrimat bar yang terbuat dari formulasi $\mathrm{P}_{2}$ berbeda nyata dengan nutrimat bar dari formulasi $\mathrm{P}_{1}, \mathrm{P}_{3}, \mathrm{P}_{4}$ dan $\mathrm{P}_{5}$ $(\mathrm{p}<0,05)$.

\section{Uji sensoris terhadap warna}

Warna yang dihasilkan pada nutrimat bar formulasi $\mathrm{P}_{1}$ lebih berwarna cokelat gelap dibandingkan dengan formulasi $\mathrm{P}_{5}$ berwarna cokelat terang. Hal ini dapat disebabkan oleh kandungan antosianin yang memberikan pigmen warna pada kacang merah. Antosianin yang menghasilkan warna merah, biru atau ungu pada berbagai jenis bahan makanan juga bisa ditemukan di blueberry, anggur merah, kol merah dan ubi ungu. ${ }^{13}$ Semakin banyak tepung kacang kedelai yang ditambahkan, maka warna nutrimat bar yang dihasilkan lebih berwarna cokelat gelap dan menjadi kurang disukai.

Hasil uji statistik menggunakan uji one way anova menunjukkan nilai $\mathrm{P}$ value $=0,000<\alpha=0,05$ maka $\mathrm{H}_{0}$ ditolak, yang artinya ada pengaruh signifikan antar formulasi tepung kacang kedelai dan tepung kacang merah terhadap karakteristik sensoris warna nutrimat bar. Hasil ini kemudian dilakukan uji lanjut dengan menggunakan uji Beda Nyata Terkecil (BNT) untuk menyatakan beda nyata antar perlakuan. Hasil uji lanjut BNT menunjukkan bahwa warna nutrimat bar yang terbuat dari formulasi $\mathrm{P}_{5}$ berbeda nyata $(\mathrm{p}<0,05)$ dengan formulasi $\mathrm{P}_{1}$ dan $\mathrm{P}_{2}$, namun tidak berbeda nyata (p>0,05) dengan formulasi $\mathrm{P}_{3}$ dan $\mathrm{P}_{4}$.

\section{Uji sensoris terhadap tekstur}

Tekstur yang dihasilkan pada nutrimat bar perlakuan $\mathrm{P}_{2}$ lebih bertekstur lembut dibandingkan dengan perlakuan $\mathrm{P}_{5}$. Hal ini dapat disebabkan oleh kandungan serat pada kacang merah merupakan sumber serat yang baik. Setiap 100 gram kacang merah kering menyediakan serat sekitar 24 gram, yang terdiri dari campuran serat larut lebih banyak dibandingkan dengan serat yang tidak larut air, sehingga serat kacang merah dapat dengan mudah digunakan di dalam pengolahan makanan dan tidak menimbulkan perubahan sifat sensori atau organoleptik makanan. ${ }^{14}$ Kombinasi tekstur nutrimat bar dengan penambahan tepung kacang merah $75 \%$ lebih disukai daripada 
nutrimat bar dengan formulasi tanpa menggunakan tepung kacang merah.

Hasil uji statistik menggunakan uji one way anova menunjukkan nilai $\mathrm{P}$ value $=0,000<\alpha=0,05$ maka $\mathrm{H}_{0}$ ditolak, yang artinya ada pengaruh signifikan antar formulasi tepung kacang kedelai dan tepung kacang merah terhadap karakteristik sensoris tekstur nutrimat bar. Hasil ini kemudian dilakukan uji lanjut dengan menggunakan uji Beda Nyata Terkecil (BNT) untuk menyatakan beda nyata antar perlakuan. Hasil uji lanjut BNT menunjukkan bahwa tekstur kelima nutrimat bar berbeda nyata $(\mathrm{p}<0,05)$. Tekstur nutrimat bar yang terbuat dari formulasi $\mathrm{P}_{2}$ berbeda nyata dengan nutrimat bar dari formulasi $\mathrm{P}_{1}, \mathrm{P}_{3}, \mathrm{P}_{4}$ dan $\mathrm{P}_{5}$ $(\mathrm{p}<0,05)$.

\section{Hasil uji sensoris keseluruhan}

Hasil uji statistik menggunakan uji one way anova menunjukkan nilai $\mathrm{P}$ value $=0,000<\alpha=0,05$ maka $\mathrm{H}_{0}$ ditolak, yang artinya ada pengaruh signifikan antar formulasi tepung kacang kedelai dan tepung kacang merah terhadap karakteristik sensoris keseluruhan nutrimat bar. Hal ini disebabkan oleh rasa, aroma, warna dan tekstur merupakan satu benang merah yang saling berkaitan dan parameter yang sangat penting dalam menentukan kesukaan suatu makanan. ${ }^{15}$ Hasil ini kemudian dilakukan uji lanjut dengan menggunakan uji Beda Nyata Terkecil (BNT) untuk menyatakan beda nyata antar perlakuan. Hasil uji lanjut BNT terhadap parameter keseluruhan kesukaan menunjukkan bahwa ada pengaruh beda nyata $(\mathrm{p}<0,05)$ antara perlakuan $\mathrm{P}_{2}$ dengan $\mathrm{P}_{5}$ dan $\mathrm{P}_{5}$ dengan $\mathrm{P}_{2}$.

\section{Hasil Uji Kandungan Zat Gizi}

\section{Uji kandungan energi}

Hasil uji statistik menggunakan uji one way anova menunjukkan nilai $\mathrm{P}$ value $=0,000>\alpha=0,05$ maka $\mathrm{H}_{0}$ diterima, yang artinya tidak ada pengaruh signifikan antar formulasi tepung kacang kedelai dan tepung kacang merah terhadap kandungan energi nutrimat bar. Hasil ini kemudian tidak dapat dilakukan uji lanjut dengan menggunakan uji Beda Nyata Terkecil (BNT) untuk menyatakan beda nyata antar perlakuan. Hal ini diduga dapat terjadi karena kandungan energi pada tepung kacang kedelai tidak berbeda dibandingkan dengan energi pada tepung kacang merah. Nilai energi per 100 gram tepung kacang kedelai 92,22 kkal dan tepung kacang merah 77,39 kkal. Semakin banyak penambahan tepung kacang kedelai pada formulasi akan meningkatkan kandungan energi pada nutrimat bar, namun peningkatan tersebut tidak cukup signifikan. Hasil uji kandungan energi pada setiap formulasi nutrimat bar sudah sesuai dengan syarat kandungan zat gizi pada makanan selingan. Snack bar umumnya dalam porsi kecil dengan kandungan zat gizi berkisar $10 \%$ dari kebutuhan energi sehari, yaitu antara 220 - 250 kkal. ${ }^{5}$

\section{Uji kandungan protein}

Formulasi penambahan tepung kacang kedelai dan tepung kacang merah dapat berbeda nyata mempengaruhi kandungan protein nutrimat bar, disebabkan oleh kandungan protein pada tepung kacang kedelai berbeda dibandingkan dengan kandungan protein pada tepung kacang merah. Nilai protein per 100 gram tepung kacang kedelai 7,22 $\mathrm{g}$ dan tepung kacang merah $1,95 \mathrm{~g}$. Semakin banyak penambahan tepung kacang kedelai pada formulasi akan signifikan meningkatkan kandungan protein pada nutrimat bar. Hasil uji kandungan protein pada formulasi nutrimat bar sudah sesuai dengan syarat kandungan zat gizi pada makanan selingan pasien kemoterapi yang memerlukan protein tinggi berkisar $20 \%$ dari kebutuhan energi sehari, yaitu antara 10-20 g. ${ }^{16}$ Hasil penelitian tentang pengaruh penggunaan tepung dan puree pisang terhadap karakteristik snack bar, juga menunjukkan data bahwa kadar protein snack bar yang terbuat dari perbandingan puree 2:1 berbeda nyata dengan snack bar yang terbuat dari perbandingan purre 1:1 dan 1:2 ( $\mathrm{p}<0,05)$. Hal ini diduga disebabkan oleh ketidakhomogenan bahan sumber protein yang digunakan dalam formulasi produk snack bar yaitu telur. ${ }^{17}$

\section{Uji kandungan lemak}

Hasil uji statistik menggunakan uji one way anova menunjukkan nilai $\mathrm{P}$ value $=0,000<\alpha=0,05$ maka $\mathrm{H}_{0}$ ditolak, yang artinya ada pengaruh signifikan antar formulasi tepung kacang kedelai dan tepung kacang merah terhadap kandungan zat gizi lemak nutrimat bar. Hasil ini kemudian dilakukan uji lanjut dengan menggunakan uji Beda Nyata Terkecil (BNT) untuk menyatakan beda nyata antar perlakuan. Hasil uji lanjut BNT terhadap parameter kandungan zat gizi lemak menunjukkan bahwa ada pengaruh beda nyata $(\mathrm{p}<0,05)$ antara perlakuan $\mathrm{P}_{5}$ dengan $\mathrm{P}_{1}$, namun tidak berbeda nyata $(p>0,05)$ dengan $P_{2}, P_{3}$ dan $P_{4}$. Formulasi penambahan tepung kacang kedelai dan tepung kacang merah dapat berbeda nyata mempengaruhi kandungan lemak nutrimat bar terutama $\mathrm{P}_{1}$ dengan $\mathrm{P}_{5}$. Hal ini diduga disebabkan oleh kandungan lemak pada tepung kacang kedelai berbeda dibandingkan dengan kandungan lemak pada tepung kacang merah. Nilai lemak per 100 gram tepung kacang kedelai $4 \mathrm{~g}$ dan tepung kacang merah $0,71 \mathrm{~g}$. Semakin banyak penambahan tepung kacang kedelai pada formulasi akan signifikan meningkatkan kandungan lemak pada nutrimat bar. Hasil uji kandungan lemak pada formulasi nutrimat bar sudah sesuai dengan syarat kandungan zat gizi pada makanan selingan pasien kemoterapi yang memerlukan lemak sedang berkisar 
15\% dari kebutuhan energi sehari, yaitu antara $4-10$ g. ${ }^{16}$

\section{Uji kandungan karbohidrat}

Hasil uji statistik menggunakan uji one way anova menunjukkan nilai $\mathrm{P}$ value $=0,000>\alpha=0,05$ maka $\mathrm{H}_{0}$ diterima, yang artinya tidak ada pengaruh signifikan antar formulasi tepung kacang kedelai dan tepung kacang merah terhadap kandungan zat gizi karbohidrat nutrimat bar. Hasil ini kemudian tidak dapat dilakukan uji lanjut dengan menggunakan uji Beda Nyata Terkecil (BNT) untuk menyatakan beda nyata antar perlakuan. Hal ini dapat terjadi karena kandungan karbohidrat pada tepung kacang kedelai tidak berbeda dibandingkan dengan kandungan karbohidrat pada tepung kacang merah. Nilai karbohidrat per 100 gram tepung kacang kedelai 34,8 g dan tepung kacang merah 56,2 g. Semakin banyak penambahan tepung kacang merah pada formulasi akan meningkatkan kandungan karbohidrat pada nutrimat bar, namun peningkatan tersebut tidak cukup signifikan. Hasil uji kandungan karbohidrat pada setiap formulasi nutrimat bar sudah sesuai dengan syarat kandungan zat gizi pada makanan selingan untuk pasien kemoterapi. Snack bar umumnya dalam porsi kecil dengan kandungan karbohidrat cukup berkisar $60 \%$ dari kebutuhan energi sehari, yaitu $20-40$ g. ${ }^{5}$

\section{Uji kandungan antioksidan}

Hasil uji statistik menggunakan uji one way anova menunjukkan nilai $\mathrm{P}$ value $=0,000>\alpha=0,05$ maka $\mathrm{H}_{0}$ diterima, yang artinya tidak ada pengaruh signifikan antar formulasi tepung kacang kedelai dan tepung kacang merah terhadap kandungan zat gizi antioksidan nutrimat bar. Hasil ini kemudian tidak dapat dilakukan uji lanjut dengan menggunakan uji Beda Nyata Terkecil (BNT) untuk menyatakan beda nyata antar perlakuan. Hal ini diduga dapat terjadi karena kombinasi kedua tepung pada formulasi nutrimat bar tidak jauh berbeda, sehingga nilai hasil uji kandungan antioksidan nutrimat bar juga menunjukkan nilai yang tidak jauh berbeda. Nilai antioksidan per 100 gram tepung kacang kedelai 135, $27 \mathrm{~g}$ dan tepung kacang merah $220,57 \mathrm{~g}$. Semakin banyak penambahan tepung kacang merah pada formulasi akan meningkatkan kandungan antioksidan pada nutrimat bar, namun peningkatan tersebut tidak cukup signifikan. Pengolahan tepung kacang kedelai dan tepung kacang merah menjadi nutrimat bar menunjukkan penurunan yang signifikan pada aktivitas antioksidan. Hasil ini sejalan dengan penelitian yang dilakukan pada tahun 2013 tentang Sorghum Tea yang menyatakan bahwa sorgum yang direndam terlebih dahulu sebelum diolah secara dipanggang menunjukkan aktivitas antioksidan yang lebih rendah yakni $25,66 \%$ dibandingkan sorgum mentahnya yakni
40,46\%. ${ }^{18}$ Aktivitas antioksidan tertinggi terdapat pada nutrimat bar dengan formulasi $\mathrm{P}_{1}$ (tepung kacang kedelai $0 \%$ : tepung kacang merah 100\%) dengan karakteristik warna cokelat gelap. Warna cokelat pada nutrimat bar menunjukkan adanya kandungan proantosianidin (tanin terkondensasi) yang tinggi. Proantosianidin merupakan sumber antioksidan terbaik. ${ }^{19}$ Pasien kanker yang menjalani pengobatan kemoterapi mengalami stress oksidatif yang ditandai dengan peningkatan radikal bebas dan penurunan fungsi antioksidan primer (antioksidan endogen) seperti superoxide dismutase (SOD), catalase (CAT) dan glutathione peroxidase. ${ }^{20}$ Oleh karenanya, pasien perlu mengasup pangan sumber antioksidan (antioksidan eksogen) sebagai antioksidan sekunder yang membantu kerja antioksidan primer. ${ }^{4}$ Fungsi antioksidan makanan didalam tubuh dapat diamati melalui biomarker plasma antioxidant capacity (PAC). PAC meliputi aktivitas antioksidan dari makanan dan antioksidan endogen. PAC menunjukkan biomarker penyerapan antioksidan makanan dalam tubuh. Apabila antioksidan makanan terserap, PAC akan meningkat. ${ }^{21}$

\section{Hasil Pemilihan Formulasi Nutrimat Bar Terbaik}

Formulasi terbaik nutrimat bar berdasarkan total nilai hasil $(\Sigma \mathrm{Nh})$ yang tertinggi pada Tabel 3 adalah $\mathrm{P}_{2}$ dengan penambahan tepung kacang kedelai $25 \%$ : tepung kacang merah 75\%. Hasil ini dapat terjadi karena kombinasi kedua tepung dapat menghasilkan nilai keseluruhan kesukaan (rasa, aroma, warna dan tekstur) dan nilai kandungan zat gizi (energi, protein, lemak, karbohidrat dan antioksidan) tertinggi pada formulasi $\mathrm{P}_{2}$. Formulasi $\mathrm{P}_{2}$ menghasilkan nutrimat bar dengan rasa enak, aroma gurih, warna cokelat dan tekstur lembut, yang memiliki kandungan zat gizi energi $232,18 \mathrm{kkal}$, protein $12,75 \mathrm{~g}$, lemak 4,71 g, karbohidrat 35,36 $\mathrm{g}$ dan antioksidan $84,69 \mathrm{mg} / \mathrm{L}$ GAEAC. Karakteristik mutu nutrimat bar yang dihasilkan sangat sesuai dengan syarat makanan bagi pasien kemoterapi yang memerlukan makanan dengan porsi kecil, rasa dan penampilan menarik dengan kandungan energi dan protein tinggi.

\section{SIMPULAN}

Formulasi tepung kacang kedelai dan tepung kacang merah mempengaruhi karakteristik nutrimat bar baik dari karakteristik sensoris (rasa, aroma, warna dan tekstur) maupun kandungan zat gizi terutama protein dan lemak. Formulasi terbaik nutrimat bar adalah $\mathrm{P}_{2}$ (tepung kacang kedelai $25 \%$ : tepung kacang merah $75 \%$ ) yang menghasilkan karakteristik rasa gurih, aroma tidak langu, warna cokelat dan tekstur lembut, dengan nilai kandungan zat gizi energi 232,18 kkal, protein 12,75 g, lemak 4,71 g, karbohidrat 35,36 $\mathrm{g}$ dan antioksidan 84,69 mg/L GAEAC. 


\section{SARAN}

Perlu penelitian lebih lanjut tentang tingkat kesukaan produk nutrimat bar yang kepada pasien untuk mengetahui daya terima pasien terhadap nutrimat bar sebagai makanan alternatif bagi pasien kemoterapi. Perlu pengujian daya simpan produk nutrimat bar yang dihasilkan untuk mengetahui tingkat keawetan selama penyimpanan.

\section{DAFTAR PUSTAKA}

1. Donaldson MS. Nutrition and Cancer : A Riview of The Evidence for an Anti-Cancer Diet. Nutrition Journal. 2004; 3(1): 19-22.

2. Hudayani F. Gangguan Makan Pasca Kemoterapi dan Radiasi. [Online] 2012 [cited 2017 Peb 13]. Available from : http://gizi.depkes.go.id/wpcontent/uploads/2012/05/Ganggn-mkn-pascakemotrp.pdf.

3. Mahan MK and Arlin MT. Krause's Food, Nutrition and Diet Therapy. Philadelphia : WB. Saunders; 2012.

4. Winarsi H. Antioksidan Alami dan Radikal Bebas. Yogyakarta : Kanisius; 2005.

5. Hakim VR dan Fitriyono. Analisis Aktivitas Antioksidan, Kandungan Zat Gizi Makro dan Mikro Snack Bar Beras Warna Sebagai Makanan Selingan Penderita Nefropati Diabetik. Journal of Nutrition College [Online] 2013 [cited 2017 Peb 13]; 2(4): 431-438. Available from : http://ejournal-s1.undip.ac.id/index.php/jnc.

6. Skolnik $\mathrm{H}$ and Chernus A. Nutrient Timing for Peak Performance (The Rights Food, The Rights Time, The Rights Results). [e-book]. 2010 [cited 2017 Peb 13]. Available from : http://www.humankinetics.com/products/allproducts/nutrient-timing-for-peak-performanceebook.

7. Instalasi Gizi RSUP Sanglah. Laporan Tahunan. Denpasar : RSUP Sanglah; 2016.

8. Riwan. Sifat-Sifat Organoleptik Dalam Pengujian Terhadap Bahan Pangan. [Online]. 2005 [cited 2017 Peb 13]. Available from : htttp://www.ubb.ac.id.

9. Yitnosumarto S. Percobaan : Perancangan, Analisis dan Interpretasinya. Jakarta : PT Gramedia; 1993.

10. Winarsi H. Protein Kedelai dan Kecambah Manfaat Bagi Kesehatan. Yogyakarta : Kanisius; 2010.
11. Verawati. Pengaruh Substitusi Tepung Kacang Merah Terhadap Kualitas Kulit Pie. Skripsi. Program Studi Pendidikan Kesejahteraan Keluarga Fakultas Teknik Universitas Negeri Padang; 2015.

12. Mufti M. Bau Langu Pada Susu Kedelai. Halaman Putih [Online]. 2008 [cited 2017 Peb 13]. Available from https://id.wikipedia.org/wiki/Kedelai.

13. Gould K. Anthocyanins, Biosynthesis, Functions and Applications. Springer Journal 2008; ISBN 978-0-387-77334-6, p. 283-298.

14. Afriansyah N. Kacang Merah Turunkan Kolesterol dan Gula Darah. [Online]. 2007 [cited 2017 Peb 13]. Available from : http://www.fmipa.ipb.ac.id.

15. Septiani VE, Indrus J dan Wijaya $H$. Pembuatan Snack Bar Bebas Gluten dari Bahan Baku Tepung Mocaf dan Tepung Beras Pecah Kulit. Skripsi. Program Studi Ilmu Gizi Fakultas Ilmu Kesehatan Sains dan Teknologi Universitas Esa Unggul Jakarta; 2015.

16. Almatsier S. Penuntun Diet Edisi Terbaru. Jakarta : PT. Gramedia Pustaka Utama; 2010.

17. Ekafitri R. Pengaruh Penggunaan Tepung dan Puree Pisang Terhadap Karakteristik Mutu Makanan Padat Berbasis Pisang. Journal Penelitian Gizi dan Makanan 2013; 36(2): 127134.

18. Isdamayani L. Kandungan Flavonoid, Total Fenol, Dan Antioksidan Snack Bar Sorgum Sebagai Alternatif Makanan Selingan Penderita Diabetes Mellitus Tipe 2. Skripsi. Program Studi Ilmu Gizi Fakultas Kedokteran Universitas Diponegoro; 2015.

19. Rhodes DH, Hoffmann L, Rooney WL, Ramu P, Morris GP, Kresovich S. Genome-wide association study of grain polyphenol concentrations in global sorghum [Sorghum bicolor (L.) Moench] germplasm. Journal Agriculture Food Chemical, 2014; 62: 10916-27.

20. Maritim AC, Sanders RA, Watkins JB. Diabetes, Oxidative Stress, and Antioxidants. a review. Journal Biochem Molecular Toxicology 2003; 17(1): 24-38.

21. Fernandez-Panchon MS, Villano D, Troncoso AM, Garcia-Parrilla MC. Antioxidant Activity of Phenolic Compounds : From In Vitro Results to In Vivo Evidence. Critical Reviews in Food Science and Nutrition Journal 2008; 48: 649-671. 